\section{Measurements of the Age of the Vallorcine Granite (Switzerland)}

Tee Vallorcine granite is located in the external crystalline massif of the Aiguilles-Rouges (Switzerland). The shape of the granite outcrop is narrow $(1 \mathrm{~km}$.) and long $(20 \mathrm{~km}$.) with a direction southsouth-west-north-north-east. It is situated between the Rhône Valley on the north and the Arve Valley on the south. While its extreme southern part is in French territory, the remaining part is in Swiss territory. This granite is generally porphyritic, and the grain is a medium or fine one. Its texture is massive, with no orientations, and it is composed chiefly of quartz, microcline, biotite and plagioclase (oligoclase-andesine).

This granite is clearly an intrusive one. It has two different types of contact with the surrounding rocks; westward there is a normal intrusive contact with gneiss; eastward there is a tectonic contact separating the granite from the schists and grés of the Upper Carboniferous through a very important mylonite zone along the Remua fault. The mylonite has been determined probably by the late Hercynian orogeny.

Krummenacher ${ }^{1}$ suggested localizing the geological age of this granite in a period preceding the deposition of the Upper Carboniferous sediments. On the contrary, Krummenacher and Evernden², using the results of the potassium/argon age determination method as a basis (225 million years), proposed a Permian or Upper Carboniferous age as a possible one. It was thought of some interest to study again the Vallorcine granite from different points of view. In fact the absolute age was determined on the biotitic fraction by the rubidium/strontium method, and later on measurements were made on the lattice parameters of zircons and the density of the pleochroic halos in biotite crystals.

The sample studied was collected in the extreme northerm part of the massif in the Miéville quarry.

The results are given in Tables 1 and 2 , from which it can be seen that, while the rubidium/strontium age is $286+10 \mathrm{~m} . \mathrm{y}$., the age deduced from the measurement of lattice parameters in zircons is $127 \pm 10 \mathrm{~m} . \mathrm{y}$. Further on, the pleochroic halos show a very young age (Fig. 1), lower than that of Elba granodiorite halos, which have been used, until now, as a standard. The biotites from the Elba granodiorite and from the Vallorcine granite, artificially irradiated with a polonium-210 $\alpha$-particle source, show very close sensitivities.

The absolute age of the Elba (M. Capanne) granodiorite measured by means of the rubidium-strontium method on three different minerals ${ }^{3}$ is $7 \mathrm{~m} . \mathrm{y}$.

Table 1. RUBIDIUM-STRONTIUM RESULTS

$\begin{array}{ccccc} & \text { Comm. Sr } & \text { Rd. }{ }^{87} \mathrm{Sr} & \text { Rd. }{ }^{87} \mathrm{Sr} & \\ \text { Rb (p.p.m.) } & \text { (p.p.m.) } & \text { (p.p.m.) } & \text { Tot. }{ }^{87} \mathrm{Sr} & \text { Age (m.y.) } \\ 801 \pm 10 & 14.68 \pm 0.17 & 0.9 \pm 0.018 & 0.47 & 286 \pm 10\end{array}$

Table 2. Radiation Damage Regutts

$\begin{array}{ccc}\begin{array}{c}\text { Specific activity } \\ (\alpha / \mathrm{mgm} . \mathrm{hr} .)\end{array} & c^{\circ}\left(\AA_{.}\right) & \text {Age (m.y.) } \\ 492 \pm 15 & 5.9965 \pm 0.0008 & 127 \pm 10\end{array}$

Table 3

$\begin{array}{lcl}\quad \text { Methods } & \text { Age (m.y.) } & \text { Laboratories } \\ \text { Rb/Sr } & 286 \pm 10 & \text { Pisa, Italy } \\ \text { Ar/K } & 225 \pm 3 & \text { Geneva, Switzerland; } \\ \text { Radiation damage } & 127 \pm 10 & \begin{array}{c}\text { Bauseley, U.S.A. } \\ \text { Laune, Switzerland }\end{array} \\ \text { Pleochroic halos } & <5 & \begin{array}{l}\text { Pisa, Italy } \\ \text { Pisa, }\end{array}\end{array}$

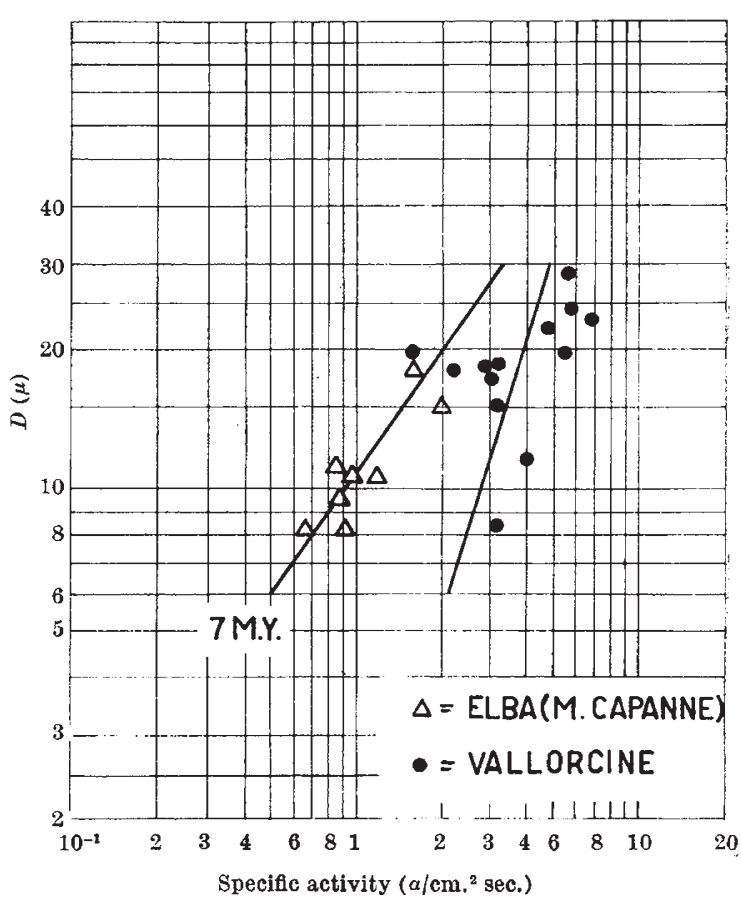

Fig. 1

From these results and from those of Krummenacher: and Evernden ${ }^{2}$ (Table 3) we can form the following. conclusions. It is well known that among the methods used to determine the age of the Vallorcine granite the rubidium-strontium one is the least sensitive to metamorphic actions. The potassium; argon method is more liable to inaccuracy because argon may easily be lost. Increasingly influenced are the results using radiation damage methods; the pleochroic halos method particularly can be considered a very highly sensitive one. On the basis of such considerations it is possible to conclude that the real absolute age of the Vallorcine granite is at least $286 \pm 10 \mathrm{~m} . \mathrm{y}$. If the rubidium-strontium age measured on biotites is not affected by metamorphic actions, the emplacement of the Vallorcine granite occurred during the Middle or Lower Stephanian. Later on, the rock certainly underwent metamorphic actions. These actions, while of unknown intensity, have nevertheless been strong enough to cause a partial loss of argon and to efface, partially or totally, the damage caused by radiation in the lattice of zircon crystals and of the surrounding biotite crystals (cf. Table 3). It can particularly be affirmed that the last metamorphic actions were very recent and certainly did not take place before the Pliocene.

\section{R. Chessex \\ F. DE Montmolitin}

Institut de Minéralogie, Lausanne, Switzerland.

\section{G. Ferrara}

A. Lonatnelli

Laboratorio di Geologia Nucleare, Pisa, Italy.

${ }^{1}$ Krummenacher, D., Bull. 8uisse Min. et Pettr., 39, 151 (1959).

${ }^{2}$ Krummenacher, D., Evernden, J. F., Bull. suisse Min. et Petr. 40/2, 267 (1960).

${ }^{3}$ Ferrara, G., Hirt, B.. Marinelli, G., and Tongiorgi, E., Boll. Soc, geol. Ital., 80 (1961). 